now known that wear can be ascribed to abrasion, flex-fatigue and the mechanical unravelling of the fabric structure, with abrasion not necessarily the most important contributor. Energy is absorbed by the fabric in abrasion, which fact provides the keystone to the recent theories of Hamburger in which tensile and abrasion properties are correlated.

H. Bradley (British Boot, Shoe and Allied Trades Research Association, Kettering), speaking on "The Abrasion and Wear of Leather", surveyed the progress made in this field in recent years. In spite of much work it has not so far proved possible to design wear-testing equipment for the rapid assessment of the wear of leather under practical conditions, and the issue of free shoes to schoolboys still provides the most reliable means for wear-testing. Dimensional analysis was suggested by Mr. Bradley as a possible basis for future research.

P. Feltham

\section{EARTHQUAKES DURING 1951}

$\mathrm{D}$ URING 1951 fourteen earthquakes caused major damage and casualties. The swarm of shocks which started on Boxing Day 1950 continued daily in the Leeward Islands during January. On Nevis, severe damage was done to the library, the hospital and to most public buildings, as also to two churches, two or three schools and the school feeding-centre. Demolition was necessary in some cases, and there was concern over the water supply. On St. Kitts two banks, the treasury and the hospital, together with some private houses and business premises, were damaged. Most of the people in these islands live in small wooden houses, which were not damaged by the shocks, and fortunately there was no loss of life or food shortage.

In New Zealand a swarm of shocks occurred during January at Cheviot, a small town sixty miles north of Christchurch. The first shock, on January 10, had magnitude $5 \cdot 6$ on the Richter logarithmic scale, and there followed some twenty-five other strong shocks during the month. Most of the chimneys in Cheviot were down, the telephone service was temporarily out of order and the Blenheim-Christchurch railway was temporarily blocked by a landslide.

A series of tremors, culminating in two strong shocks on January 14, caused heavy property damage at Angrado Heroismo in the Azores.

On March 14 earth tremors rocked parts of France, Belgium, Holland and Germany. The epicentre was probably in the Eifel plateau, and at Euskirchen the walls of a school cracked and the chimney fell down. Minor property damage in the area was extensive. On April 8 an earthquake near the coast of Turkey $\left(37^{\circ}\right.$ N., $35^{\circ}$ E.) caused casualties amounting to six killed and ten injured.

Four destructive earthquakes occurred during May. On May 6 approximately a thousand people were killed, four thousand injured, and twenty thousand rendered homeless by the earthquake which wrecked the town of Jacuapa in the Republic of El Salvador. Jacuapa is some seventy-five miles east of San Salvador. On May 10 a tremor shook southern Rhodesia, and a further twenty-four tremors continued to shake the same area during the month. A large landslide was caused by the earthquakes in the Chimanimani mountains. On May 19 an earthquake near Cordova in Spain caused such damage to the convent of St. Francis that it later collapsed. No casualties were caused, as the building had been evacuated following the initial damage. On May 31 an earthquake off the north coast of Luzon $\left(19^{\circ}\right.$ N., $121^{\circ}$ E.) in the Philippine Islands caused slight property damage, and injury to one person.

On July 9, near the east coast of Oaxaca, Mexico, one person was killed as a result of an earthquake at Miahuatlan.

On August 13, at 18h. 33m. 40s. G.M.T., a strong earthquake occurred in the Black Sea, off the coast of 'I'urkey. In the district of Kurshunlu in the province of Changari, several villages were razed and the official report states that 3,354 houses were destroyed, resulting in 50 people being killed and 208 injured. On August 21 an earthquake with epicentre near the west coast of Hawaii caused some damage to property on the Kona coast.

On October 22 , at 03 h. $29 \mathrm{~m}$. 26s. G.M.T., For mosa was shaken by a tremor which proved to be the first of a series of more than forty heavy and more than ninety minor earth tremors. The main business centre of Hualien was wrecked ; more than twenty bodies were recovered from the debris. Houses were also damaged in Tainan and Taichung. Reports state that approximately a hundred people were killed and eight hundred injured in the island. Again, on November 12, earth tremors damaged the port of Hsinkiang on the east coast of Formosa, but on November 24 a series of shocks, the greatest being at $18 \mathrm{~h} .50 \mathrm{~m}$. 19s. G.M.T. (Richter logarithmic magnitude $7 \frac{1}{4}$ ), once more shook the east coast, causing major property damage and the deaths of twelve persons. Several others were injured.

Of the earthquakes so far mentioned, only the lastnamed attained a Richter logarithmic magnitude greater than 7 , but all happened in populated districts. During the year, six other earthquakes, with epicentres in unpopulated areas, attained a Richter logarithmic magnitude greater than 7. These were on February 17 in south-east New Guinea (71),


Kermadec Islands $(7 \cdot 1)$, November 6 in the Kurile Islands (71), November 18 in eastern Tibet $\left(7 \frac{1}{2}\right)$, and December 8 in the Indian Ocean, about nine hundred

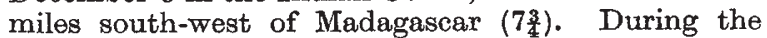
year seven earthquakes had a depth of focus greater than $250 \mathrm{~km}$. These occurred on February 9 in the Pacific Ocean between Tonga and the Kermadec Islands $(600 \mathrm{~km}$.), March 23 (previously mentioned) in the Kermadec Islands $(300 \mathrm{~km}$.), July 11 in the Bonin Islands region $(550 \mathrm{~km}$.), August 2 near the New Britain Islands $(500 \mathrm{~km}$.), August 10 off the north coast of Hokkaido (Japan) $(300 \mathrm{~km}$.), August 28 . in the Kermadec Islands region $(600 \mathrm{~km}$.), and November 12 south of the Fiji Islands $(400 \mathrm{~km}$.).

The above account is based on information received from the International Seismological Association (Strasbourg) and co-operating observatories, the Jesuit Seismological Association of Observatories (headquarters St. Louis, United States), the United States Coast and Geodetic Survey with its seismological observatories, Stuttgart and the adjoining stations, Zurich and the Swiss observatories, Wellington and the New Zealand observatories (including Fiji), Aberdeen, Belgrade, Cleveland (Ohio), De Bilt (Netherlands), Durham, Karlsruhe, Kew, Mizusawa (Japan), Pasadena, Perth (Western Australia), Toledo and Trieste.
ERnEst 'TiLLOTSON 